\title{
SKIRTINGO TRENIRUOTUMO STUDENČIŲ ŠIRDIES IR KRAUJAGYSLIŲ SISTEMOS FUNKCINIŲ RODIKLIŲ YPATUMAI
}

\author{
Ernesta Sendžikaitė ${ }^{1}$, Algė Daunoravičienè ${ }^{1}$, Alfonsas Vainoras ${ }^{1}$, Kristina Berškienè $\dot{1}^{1,2}$ \\ Kauno medicinos universitetas ${ }^{l}$, Kauno technologijos universitetas ${ }^{2}$, Kaunas, Lietuva
}

\begin{abstract}
Ernesta Sendžikaitė. Kineziologijos magistrè. Kauno medicinos universiteto Kineziologijos ir sporto medicinos katedros asistentė, doktorantė. Moksliniu tyrimų kryptis - aerobikos pratybų poveikio tyrimas jaunesnio amžiaus moterų morfofunkciniams rodikliams.
\end{abstract}

\section{SANTRAUKA}

Aerobikos pratybos tarp studenčiu populiari fizinio aktyvumo forma. Tačiau siekiant sveikata stiprinančio poveikio svarbi fizinio krūvio optimizavimo, individualizavimo problema, nes aerobikos pratybos yra grupinès ir jose dalyvauja skirtingo pajegumo, treniruotumo merginos.

Tyrimo tikslas - ¿vertinti jaunesnio amžiaus moteru širdies ir kraujagysliu sistemos funkcinius rodiklius priklausomai nuo aerobikos pratybu stažo. Tiriamoji imtis - 64 studentès (21,97 2,11 m. amžiaus), 2-3 kartus per savaite lankančios aerobikos pratybas. Pagal treniravimosi trukmę išskyreme dvi grupes: pirmos grupès merginos pratybas lankè iki metu ( $\leq 12$ mèn.; $n=36)$, antros —daugiau kaip metus (> 12 mèn.; $n=28)$. Taikyta ilgalaike EKG stebèsena (24 h), naudojant ,Cardio-Scout "aparata su penkiais elektrodais, registruojančiais dvi iprastines EKG derivacijas. Tyrimo metu nagrinèti šie dydžiai: JT intervalas, R amplitudè, QRS kompleksas ir RR intervalas.

Tyrimas parodè, kad isidirbimo dalyje daugiau nei vienerius metus aerobikos pratybas lankančiu merginu RR intervalo trukmé ilgesnè nei turinčiu mažesni staža $(p<0,05)$. Abiejose grupése didžiausio intensyvumo metu registruotos $R$ amplitudès rodikliu reikšmès skiriasi, lyginant su isidirbimo ir atsigavimo fazèmis $(p<0,05)$, tačíau pastebimas šio rodiklio stabilumas, lyginant isidirbimo ir atsigavimo fazes $(p>0,05)$. Atsigavimo metu fiksuoto QRS komplekso trukmé buvo trumpesne mažesnę treniravimosi patirtị turinčiu tiriamuju $(p<0,05)$. Taip pat mažiau treniruotu merginu QRS komplekso trukmé atsigavimo metu yra trumpesné, lyginant su isidirbimo ( $p<0,05)$, o didesni pratybu lankymo staža turinčiu merginu QRS komplekso trukme normalizuojasi greičiau $(p>0,05)$. Palyginus abi grupes pagal JT intervalo kitima krūvio ir ramybès metu, statistiškai patikimo skirtumo nenustatyta $(p>0,05)$.

Raktažoď̆iai: ŠKS funkciniai rodikliai, EKG stebèsena, aerobikos pratybos.

\section{IVADAS}

1 aujausi epidemiologiniai tyrimai patvirtina fizinio aktyvumo svarbą užkertant kelią kardiovaskulinèms ligoms ir tinkamai parinkto, individualizuoto fizinio krūvio naudą sveikatos stiprinimui (Hilberg, 2008).

Teigiama, kad dèl universitetinių studijų nepaliaujamo informacinio srauto didejimo ir mokymo proceso intensyvejjimo studentų fizinis aktyvumas yra nepakankamas, o fizinio aktyvumo didinimo problema labai aktuali: būtina tinkamai derinti studijų metu didejjanti protinị krūvị su fizinio darbo apimtimi, intensyvumu ir teigiamomis emocijomis. Irodyta, kad studentų fizinis pajègumas nepakankamas ir sveikatos būklè prastejja (Petkevičienè ir kt., 2002).

Ištyrus KMU studenčių fizinio pajègumo kaitą nustatyta, kad sportuojančių ketvirtakursiu sveikatos rodikliai daug geresni nei fiziškai pasyvių 
(Vitartaite ir kt., 2006). Irodyta, kad reguliariai lankomos aerobikos pratybos didina VPU studenčių funkcini pajègumą (Poteliūnienė ir kt., 1999).

Aerobikos pratybos - viena populiariausiu studenčiu fizinio aktyvumo forma. Apklausos metu nustatyta, kad aerobikos pratybas rinktųsi $35,1 \%$, plaukimo - 29,6\%, bėgimo - 29,9\% studentu (Muliarčikas, 2003). Daugelio autorių teigimu, aerobikos pratybos yra sveikatinimo priemone, kurios metu kompleksiškai lavinamos sveikatai svarbios fizinès ypatybès - aerobinè ištvermé, jèga ir lankstumas (Estivill ir kt., 1995; Henriksson, Tesch, 1999).

Visgi išlieka aktuali fizinio krūvio optimizavimo, individualizavimo problema, nes aerobikos pratybos yra grupinio pobūdžio ir jose dalyvauja skirtingo pajègumo, treniruotumo studentès. Didesni treniruočiu stažą turinčios merginos geriau atlieka bazinius žingsnius, geresnè jų technika, labiau susiformavę judesių igūdžiai, judesiai ekonomiškesni, ir tai leidžia joms išugdyti didesni raumenu galingumą, pratimus atliekant didesniu intensyvumu. Mažesnę treniruočių patirtị turinčios merginos, neivaldžiusios aerobikos pratybose atliekamų aciklinių žingsnių specifikos, jaučia didesnę emocinę itampą, jų judesiai mažesnès apkrovos (apmplitudès).

Hipoteż̇ - daugiau nei vienerius metus aerobikos pratybas lankančių jaunesnio amžiaus moterų širdies kraujagyslių sistemos funkcinių rodiklių adaptaciniai pokyčiai didesni.

Tikslas - ivertinti jaunesnio amžiaus moteru širdies ir kraujagyslių sistemos funkcinius rodiklius priklausomai nuo aerobikos pratybų stažo.

\section{TYRIMO METODAI IR ORGANIZAVIMAS}

Tiriamąji kontingentą sudarè 64 aerobikos pratybas lankančios Kauno medicinos universiteto studentès, kurios pagal treniravimosi trukmę buvo suskirstytos i dvi grupes: pirma - lankančios pratybas iki metu ( $\leq 12$ mènesių; $\mathrm{n}=36)$, antra - daugiau kaip metus ( $>12$ mènesių; $\mathrm{n}=28$ ). Tirtų merginų amžiaus vidurkis $-21,97 \pm 2,11$ metu. Tiriamosios aerobikos pratybas lankè vidutiniškai $2-3$ kartus per savaitę. Pratybų trukmé $-1 \mathrm{~h}$, turinys - aerobiniai, lokalieji ir tempimo pratimai.

Elektrokardiografija. EKG atlikta naudojant „Cardio Scout“ (Vokietija-Lietuva) aparatą su penkiais elektrodais. Registruotos dvi iprastinès stebėsenos metu naudojamos EKG derivacijos.
Aparatas buvo pritvirtinamas ant tiriamosios krūtinès ląstos ir EKG registruojama 24 valandas i „Flesh“ kortelę. Elektrokardiograma registruota tą dieną, kai tiriamoji dalyvavo aerobikos pratybose.

Duomenų analizei atrinkti rodiklių dydžiai, registruoti per dešimti širdies ciklų, einančių vienas po kito. Nagrinèti šie dydžiai: RR intervalasi, JT intervalas, QRS kompleksas ir R amplitudè.

Širdies ir kraujagyslių sistemos funkciniai rodikliai fiksuoti ramybės metu, atsižvelgiant $i$ mažiausią širdies susitraukimo dažnio reikšmę, kuri buvo ryte, miegant. Krūvio metu registruoti EKG rodikliai analizuoti per tris pratybu dalis: isidirbimo (5-10 min), didžiausio intensyvumo $(30-40 \mathrm{~min})$ ir atsigavimo metu (55-60 min). Isidirbimo laikotarpiu tiriamosios atliko mažos apkrovos aerobinius judesius: ivvairius žingsnius ir ju derinius. Didžiausio intensyvumo fazèje merginos atliko sudetingesnius koordinacinius judesiu junginius (su lèkimo fazėmis ir be ju) bei lokaliuosius raumenų pajėgumą didinančius pratimus. Atsigaunant buvo atliekami tempimo ir atsipalaidavimo pratimai. Atliekant statistinę duomenų analizę, apskaičiuotas kiekvienos tiriamosios nagrinèjamo rodiklio 10-ties vienas po kito fiksuotų kardiociklų matavimo vidurkis ir standartinis nuokrypis $(\sigma)$, paskui - visos grupès rodikliu ir standartinio nuokrypio vidurkis.

Tiriamosioms buvo pateikta anketa, norint sužinoti jų amžių, pratybų lankymo trukmę ir veiksnius, galinčius lemti širdies ir kraujagyslių sistemos darbą. Tiriamosios turejjo žymèti savo fizinị aktyvumą per parą.

Matematinė statistika. Statistinių duomenų analizè atlikta kompiuterinemis SPSS 10.0 for Windows ir Microsoft Excel XP programomis. Buvo apskaičiuojamas kintamujų aritmetinis vidurkis, standartinis nuokrypis. Vidurkiu skirtumo patikimumas apskaičiuotas naudojant Studento $t$ testą. Skirtumas su galima mažesne nei 0,05 paklaida buvo vertinamas kaip statistiškai patikimas.

\section{REZULTATAI}

Pratybu pradžioje RR intervalas skyrèsi priklausomai nuo tiriamujų treniruotumo $(\mathrm{p}<0,05)$. Aerobikos pratybas ilgiau nei vienerius metus lankančių merginu vidutinè RR intervalo trukmè pratybu pradžioje sieké $547,82 \pm 88,58 \mathrm{~ms}$, mažiau treniruotų — vidutiniškai 501,07 $\pm 69,55 \mathrm{~ms}$. Palyginus abiejų tiriamuju grupių didžiausio 

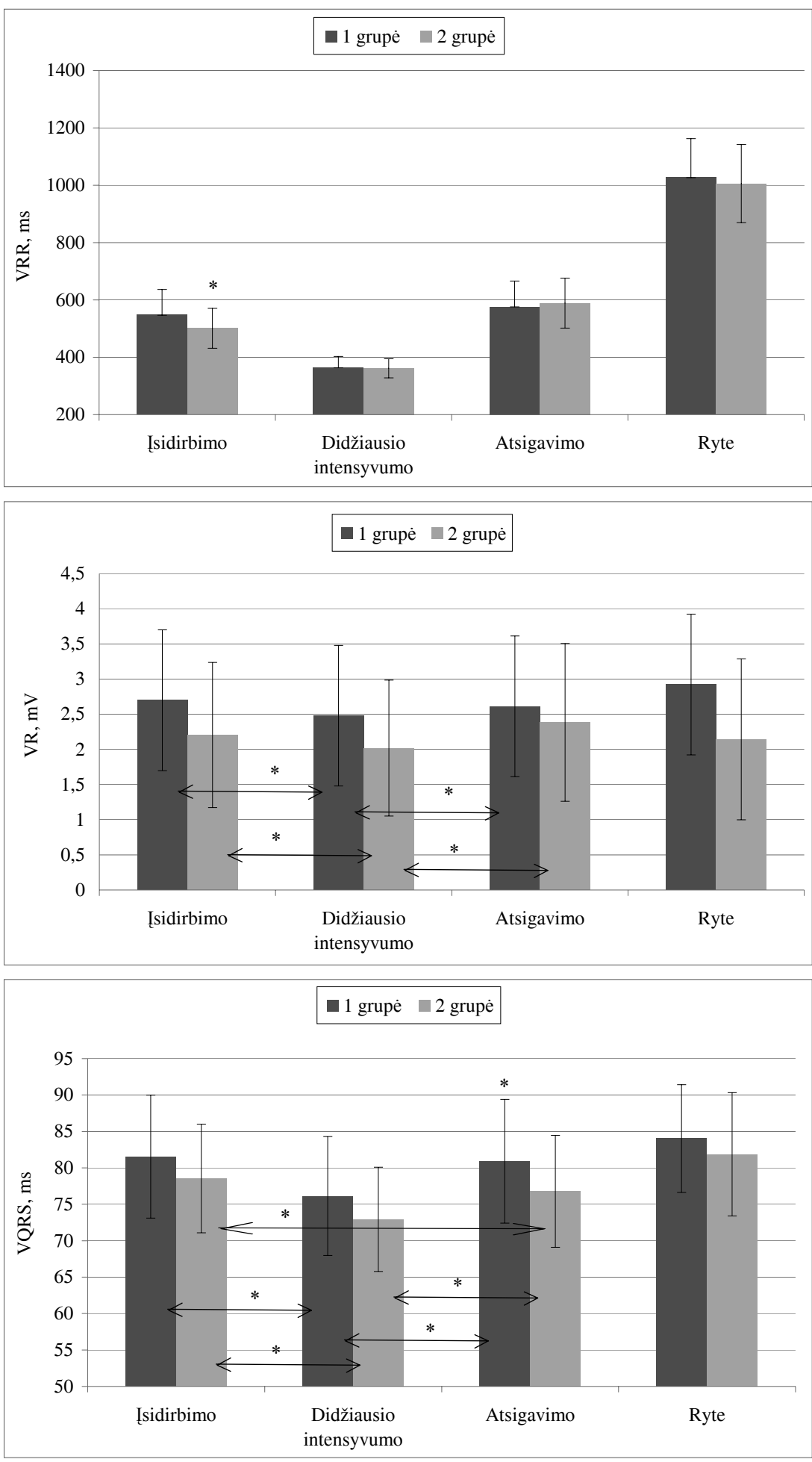

1 pav. RR intervalo kitimas skirtingo krūvio ir ramybès metu

Pastaba. $*-p<0,05$

2 pav. $\mathbf{R}$ amplitudès kitimas krūvio ir ramybès metu

Pastaba. $*-p<0,05$.

3 pav. QRS komplekso kitimas krūvio ir ramybės metu

Pastaba. $*-p<0,05$ intensyvumo ir atsigavimo metu RR intervalo trukmès vidutines reikšmes, statistiškai patikimo skirtumo nenustatyta $(p>0,05)$. Ramybès metu šio EKG rodiklio trukmè šiek tiek ilgesnè didesnị treniruočių stažą turinčių merginų $(1027,48 \pm 135,20 \mathrm{~ms})$, lyginant su mažiau treniruotuc (1005,92 $\pm 136,03 \mathrm{~ms})$.

Antrame paveiksle matyti, kad $\mathrm{R}$ amplitudès reikšmès per visas aerobikos pratybų dalis ir ramybès metu šiek tiek didesnès pirmos gru- pès merginų, tačiau statistiškai patikimo skirtumo nenustatyta $(p>0,05)$. Pratybu pradžioje $\mathrm{R}$ amplitudès vidurkis pirmoje grupèje siekè 2,70 $\pm 1,20 \mathrm{mV}$, antroje $-2,20 \pm 1,03 \mathrm{mV}$, didžiausio intensyvumo taške - atitinkamai $2,48 \pm 1,20$ ir $2,02 \pm 0,97 \mathrm{mV}$. Atsigavimo laikotarpiu nagrinèjamo rodiklio vidutinès reikšmès buvo $2,61 \pm 1,11 \mathrm{mV}$ (1 grupès) ir $2,38 \pm 1,12 \mathrm{mV}$ (2 grupès), ramybès metu - atitinkamai $2,92 \pm 2,22$ ir $2,14 \pm 1,14 \mathrm{mV}$. 


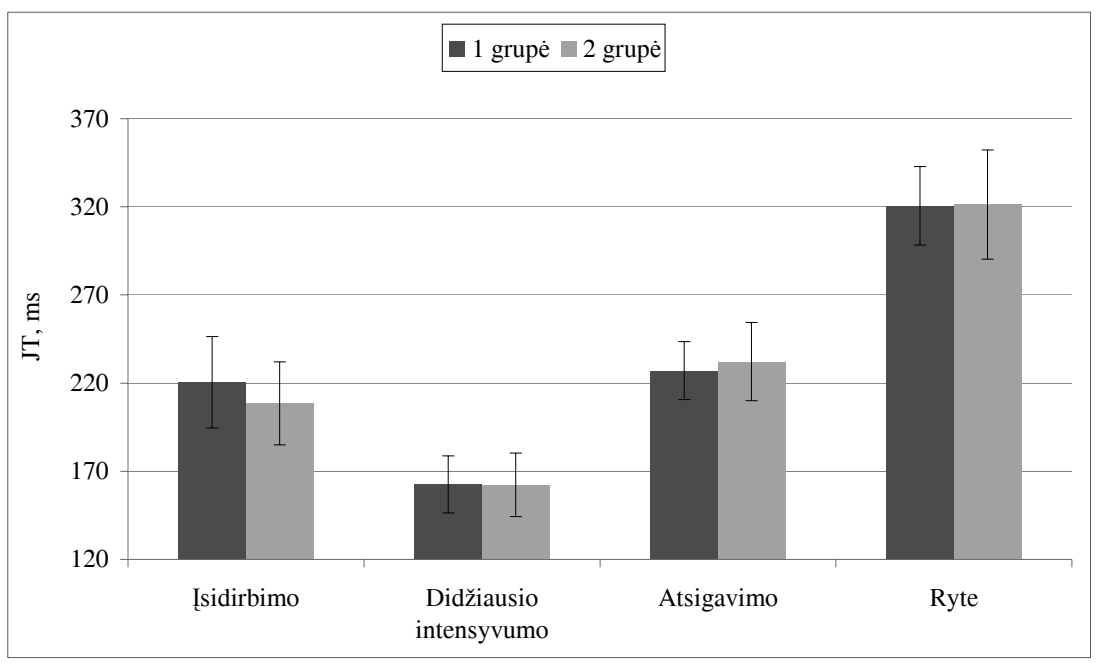

Tyrimo dumenys parodè, kad tiek pirmos, tiek ir antros grupès tiriamujų $\mathrm{R}$ amplitudès rodiklių vidurkiai pratybu pradžioje ir atsigavimo metu nesiskiria $(\mathrm{p}>0,05)$, o palyginus pratybu pradžioje ir atsigavimo metu fiksuotas reikšmes su didžiausio intensyvumo rodikliais, pastebètas reikšmingai patikimas skirtumas $(\mathrm{p}<0,05)$.

Palyginus abiejų grupių tiriamujų QRS komplekso reikšmių rezultatus nustatyta, kad atsigavimo laikotarpiu mažiau treniruotų tiriamuju šio rodiklio reikšmė $(76,77 \pm 7,69 \mathrm{~ms})$ statistiškai patikimai mažesnè nei turinčių didesni pratybų stažą $(80,91 \pm 8,50 \mathrm{~ms} ; \mathrm{p}<0,05)$. Panaši tendencija pastebima ir pratybų pradžioje, didžiausio intensyvumo ir ramybès metu, tačiau reikšmingo skirtumo nenustyta $(\mathrm{p}>0,05)$.

Lyginant QRS komplekso trukmès kitima krūvio metu, reikšmès nesiskyrè treniruotesniu merginu grupejje pratybų pradžioje ir atsigavimo metu $(p>0,05)$. Atskirų grupių šio EKG rodiklio reikšmès pratybu pradžioje ir atsigavimo metu skyrèsi, lyginant su didžiausio intensyvumo metu užregistruotomis $(p<0,05)$.

Lyginant merginas pagal treniruotumą aerobikos pratybu ir ramybès metu, nenustatyta JT intervalo trukmès patikimai reikšmingo skirtumo $(p>0,05)$. Mažiausia JT intervalo trukmé pastebèta didžiausio intensyvumo metu abiejose grupèse: pirmoje $-162,56 \pm 16,14 \mathrm{~ms}$, antroje $-162,31 \pm 18,01 \mathrm{~ms}$. Pratybu pradžioje nedaug ilgesnè JT intervalo trukmė užregistruota daugiau nei vienerius metus pratybas lankančiu merginų grupeje $(220,43 \pm 25,94 \mathrm{~ms})$, lyginant su mažiau treniruotomis $(208,53 \pm 23,62 \mathrm{~ms}$; $\mathrm{p}>0,05)$. Atsigavimo metu didesni treniruočių stažą turinčių studenčių JT intervalo trukmè siekè 227,15 $\pm 16,49 \mathrm{~ms}$, mažesni $232,24 \pm 22,21 \mathrm{~ms}$.

\section{REZULTATŲ APTARIMAS}

Dèl organizmo sistemų inertiškumo ir būtinumo pritaikyti organizmo veiklą naujomis sąlygomis, pradžioje issidirbama, t. y. organizmas pamažu isitraukia į fizini darbą. Jo metu organizmo veikla kryptingai kinta dèl reguliacinių sistemų: CNS ir vidaus sekrecijos liauku bei suderintos informacijos perdavimo receptoriams apie mechanini, metabolini poveiki. Isidirbama ne tik fizinès, bet ir protinès veiklos pradžioje.

Elektrokardiogramos RR intervalu vertinama reguliaciné sistema. Manoma, kad RR intervalu trukmès svyravimai susiję su kvėpavimo procesu: ¡̨kvėpiant jų trukmė mažěja, širdies susitraukimu dažnis didèja; iškvepiant RR intervalo trukmè didejja, širdies susitraukimo dažnis mažèja. RR intervalo trukmė fizinio krūvio pradžioje sumažeja dèl simpatinès nervų sistemos suaktyvèjimo (Skirius, 2005). Atlikto tyrimo duomenys parodè, kad isidirbimo fazèje daugiau nei metus aerobikos pratybas lankančiu merginu RR intervalo trukmé buvo ilgesnè nei mažesnị treniruočių stažą turinčių tiriamujų. Todèl galima manyti, kad pratybu pradžioje treniruotesnių studenčių reguliacinès sistemos labiau prisitaiko, jų širdis dirba lètesniu ritmu.

Kita vertus, aerobikos pratybos labai emocingos - jų turinị sudaro ịvairūs aciklinių žingsnių junginiai skambant muzikai. Patyrimo, judesiu igūdžių stoka ir emociniai veiksniai galèjo lemti mažiau treniruotų merginų reguliacinių sistemų, ypač simpatinès, suaktyvejjimą pratybu pradžioje.

Pastebèta, kad per didžiausio intensyvumo pratybas didesnị treniruočių stažą turinčios merginos, lyginant su mažiau treniruotomis, atlieka didesnès apkrovos ir amplitudés kojų bei rankų judesius, 
todèl pasiekia didesni fizinio krūvio intensyvumą. Dèl skirtingo raumenu galingumo per didžiausio intensyvumo pratybas, taip pat ir atsigavimo metu RR inetervalo reikšmès, lyginant grupiu pagal lankymo stažą rezultatus, nesiskyrè, t. y. pirmos grupès tiriamosios pasiekè didesni darbo intensyvumą ir dẻl to jų širdies ritmas buvo dažnesnis, o antros - atlikdamos nors ir mažesni krūvị, dèl nepakankamos patirties patyré didesni stresą, bet ju širdies ritmas buvo taip pat dažnas.

Teigiama, kad dèl netinkamų krūvių ar per mažo treniruotumo gali sumažèti $\mathrm{R}$ dantelio amplitudè, o šio rodiklio kitimas rodo gerą funkcinę būklę. Vertinant gautus rezultatus nustatyta, kad daugiau nei vienerius metus aerobikos pratybas lankančių studenčiu $\mathrm{R}$ amplitudès reikšmès šiek tiek didesnès tiek krūvio, tiek ramybès metu $(p>0,05)$, o jos kintamumas didesnis treniruotesnių merginu grupèje. Jeigu ši rodiklị netiesiogiai sietume su plaučiu funkcija (amplitudès mažejimas rodo didesni plaučiu oringumą ir tuo pačiu didesnę varžą juose bei didesni itampos kritimą, t. y. $\mathrm{R}$ amplitudę, ir, priešingai, amplitudès didejimas rodo didesni priplūdusio ị plaučius kraujo kieki ir mažesni oringumą), tai labiau treniruotu merginu šio rodiklio svyravimas, lyginant su antra grupe, gali būti siejamas su geresniu jų prisitaikymu prie fizinio krūvio.

Ištyrus $\mathrm{R}$ amplitudès kaitą per aerobikos pratybas nustatyta, kad abiejose grupėse didžiausio intensyvumo metu registruotų rodiklių reikšmès skiriasi, lyginant su įsidirbimo ir atsigavimo fazèmis $(p<0,05)$. Galima manyti, kad šiuos pokyčius lèmė krūtinès varžos kaita, susijusi su kvėpavimo pokyčiais didžiausio intensyvumo metu.

QRS komplekso trukmè rodo laidumą skilveliuose. Normalaus QRS komplekso trukmè 60-100 ms (Silverman et al., 1983). Nustatyta, kad treniruotu sportininkų QRS kompleksas ramybès sąlygomis daug didesnis negu nesportuojančiuju ir siekia viršutinę normos ribą. Asmenims, turintiems širdies raumens hipertrofija, QRS komplekso trukmė gali viršyti $100 \mathrm{~ms}$ (Skirius, 2005). Tyrimo metu nustatyta, kad rytinio QRS komplekso trukmė atitiko normos reikšmes: $84,03 \pm 7,39 \mathrm{~ms}$ užregistruota pirmoje grupejje, $81,87 \pm 8,47 \mathrm{~ms}$ - antroje.

Fizinio krūvio metu trumpejjant širdies ciklui, ir esant didesniam simpatinès sistemos poveikiui, trumpèja QRS komplekso trukmè. Krūvio metu registruoto QRS komplekso trukmè buvo ilgesnè tarp didesni stažą turinčiu studenčiu. Atsigavimo metu nustatytas statistiškai patikimas skirtumas, lyginant abieju grupiu QRS komplekso trukmès reikšmes, ir tai gali būti susiję su adaptaciniais morfofukciniais ŠKKS pokyčiais dèl reguliarių aerobikos pratybu.

Greiti atsigavimo procesai liudija apie tinkamai parinktą krūvị. Visgi tyrimo metu nustatyta, kad mažiau nei vienerius metus aerobikos pratybas lankančiu studenčiu atsigavimo metu fiksuoto dydžio reikšmė nepasiekè pradinio lygio ir buvo mažesné, lyginant su isidirbimo metu nustatyta reikšme $(p>0,05)$. Manome, kad šios grupès merginoms būdinga didesnè simpatinè aktyvacija.

JT intervalo (elektrokardiogramoje nuo jungties $J$ iki $T$ bangos pabaigos) trukmé atitinka širdies elektrinę sistolę ir jo trumpejimas susijęs su metabolizmo intensyvèjimu fizinio krūvio metu. Reguliarūs fiziniai pratimai lemia ŠKS adaptacinius pokyčius: gerèja kraujotaka širdies vainikinèse kraujagyslèse, didejja kraujo kiekis, eritrocitu ir hemoglobino kiekis (Vitartaite ir kt., 2004). Nagrinėjant JT intervalo rodikliu pokyčius abiejose tiriamuju grupèse fizinio krūvio ir ramybès metu, patikimo skirtumo nepastebèta. Nedidelis šio rodiklio, kaip ir RR intervalo, reikšmių skirtumus isidirbimo ir atsigavimo metu galejo lemti per aerobikos pratybas išugdomas skirtingas intensyvumas, nevienodas širdies apkrovimas vykdant hemodinaminę funkciją krūvio metu.

Tyrimo rezultatai patvirtino hipotezę, kad aerobikos pratybų lankymo stažas turi įtakos jaunesnio amžiaus moterų širdies kraujagyslių sistemos funkcinių rodiklių adaptaciniams pokyčiams.

\section{IŠVADOS}

1. Daugiau nei vienerius metus aerobikos pratybas lankančių merginų RR intervalo trukmè issidirbimo dalyje ilgesnè nei turinčių mažesnị teniruočių stažą.

2. Aerobikos pratybu isidirbimo ir atsigavimo didžiausio intensyvumo metu registruotos EKG R dantelio amplitude mažesnè, lyginant su įsidirbimo ir atsigavimo fazèmis.

3. Atsigavimo metu fiksuoto QRS komplekso trukmė buvo trumpesnè mažesnę treniravimosi patirti turinčių tiriamujų. Mažiau treniruotu merginu QRS komplekso trukmè atsigavimo metu yra trumpesnè, lyginant su įsidirbimu, o didesni pratybų lankymo stažą turinčių merginų QRS komplekso trukmė normalizuojasi greičiau. 


\title{
LITERATŪRA
}

Henriksson, J., Tesch, P. (1999). Current knowledge on muscle training: Endurance and strength yield complementary effects. Lakartidningen, $696(1-2), 56-60$.

Hilberg, T. (2008). Physical activity in the prevention of cardiovascular diseases. Epidemiology and mechanisms. Hamostaseologie, 28 (1), 9-15.

Estivill, M. (1995). Therapeutic aspects of aerobic dance participation. Health Care for Women International, 16 (4), 341-350.

Muliarčikas, A. (2003). Kauno studentų laisvalaikio fizinis aktyvumas ir ji lemiantys faktoriai. Ugdymas. Küno kultūra. Sportas, 5 (50), 44-51.

Petkevičienè, J., Kardelis, K., Misevičienè, I., Petrauskas, D. (2002). Kauno aukštųjų mokyklų studentų fizinio aktyvumo, žalingu ipročių ir studiju krypties sąsaja. Ugdymas. Kūno kultūra. Sportas, 4 (45), 77-84.
Poteliūnienè, S., Skernevičius J., Mertinas, J. (1999). Aerobika - papildoma kūno kultūros priemonè studenčiu funkciniam pajègumui ir fiziniam darbingumui gerinti. Sporto mokslas, 4 (18), 56-62.

Silverman, M. E. Myerburg, R. J., Hurst, J. W. (1983). Elektrocardiography, Basic Concepts and Clinical Aplication. New York: McGraw-Hill Book Company. P. 45.

Skirius, J. (2005). Sporto medicina: funkciness bukles medicinine kontrolè. Kaunas: LKKA. P. 134-145.

Vitartaite, A., Šiupšinskas, L., Bieliūnas, V. V. ir kt. (2006). Kauno medicinos universiteto studenčių fizinio pajègumo kaita. Ugdymas. Küno kultūra. Sportas, 1 (60), 84-91.

Vitartaite, A., Vainoras, A., Sedekerskienė, V., Poderys, J. (2004). Sveikatingumo aerobikos pratybu poveikis $30-40$ metų moterų širdies ir kraujagyslių sistemos funkciniams rodikliams. Medicina, 40 (5), 451—457.

\section{PECULIARITIES OF FUNCTIONAL INDICATORS OF CARDIOVASCULAR SYSTEM DEPENDING ON DIFFERENT TRAINING EXPERIENCE OF STUDENTS}

\author{
Ernesta Sendžikaite் ${ }^{1}$, Algė Daunoravičiené ${ }^{1}$, Alfonsas Vainoras ${ }^{1}$, Kristina Berškienè $\dot{1}^{1,2}$ \\ Kaunas University of Medicine ${ }^{l}$, Kaunas University of Technology, Kaunas, Lithuania
}

\begin{abstract}
The aim of this research was to study the adaptation of functional indicators of cardiovascular system depending on the standing of the aerobic classes.

The sample consisted of 64 young female students $(21.97 \pm 2.11$ years old $)$, involved in aerobics exercise program (2-3 times per week). Depending on their experience in the aerobic classes the participants were divided into two groups: the first group - women participating in aerobics classes less than a year $(\leq 12$ months; $\mathrm{n}=36)$ and the second group - women participating in aerobics classes more than a year $(>12$ months; $\mathrm{n}=28$ ). All data were recorded (24 hours) using the specialized system „Cardio-Scout“ with five electrodes recording two derivations. The following electrocardiographic parameters were evaluated: JT intervals, $\mathrm{R}$ amplitude, QRS complex ir RR intervals.

The results of the research showed that in the first group we assessed the adaptation of functional indicators of the cardiovascular system. In the first group RR intervals during the first low intensity phase and QRS complex during the recovery phase were longer than in the second group $(p<0.05)$. In the first goup the term of QRS complex during the first low-intensity phase and the recovery phase $(p>0.05)$ remained the same. However, in the second group it decreased $(p<0.05)$. In both groups the amplitude of $\mathrm{R}$ wave during the highest intensity phase ranged in comparison with the first low-intensity phase and the recovery phase $(p<0.05)$. The term of JT intervals in different groups of participants during aerobics classes and the rest phases did not differ $(\mathrm{p}>0.05)$.
\end{abstract}

Keywords: cardiovascular system, functional indicators, ECG, aerobics.

Gauta 2008 m. gegužès $1 \mathrm{~d}$.

Received on May 1, 2008

Priimta $2008 \mathrm{~m}$. birželio $18 \mathrm{~d}$.

Accepted on June 18, 2008
Ernesta Sendžikaitė

Kauno medicinos universitetas

(Kaunas University of Medicine)

M. Jankaus g. 2, LT-50275 Kaunas

Lietuva (Lithuania)

$\mathrm{Tel}+37037730580$

E-mail ernestasendzik@gmail.com 